Research Paper

\title{
Phenotypic and genotypic characterization of Streptococcus agalactiae in pregnant women. First study in a province of Argentina
}

\author{
P Oviedo, E Pegels, M Laczeski, M Quiroga, M Vergara \\ Facultad de Ciencias Exactas, Químicas y Naturales, Universidad Nacional de Misiones, Posadas, \\ Misiones, Argentina.
}

Submitted: December 22, 2010; Approved: July 2, 2012.

\begin{abstract}
Group B Streptococcus (GBS) is the leading cause of neonatal infections. Our purpose was to characterize GBS colonization in pregnant women, current serotypes, resistance phenotypes and genes associated with virulence. In Misiones, Argentina, there are no previous data on this topic. Vaginalrectal swabs from 3125 pregnant women were studied between 2004 and 2010. GBS strains were identified by conventional and serological methods (Phadebact Strep B Test, ETC International, Bactus AB, Sweden). Serotypes were detected using Strep-B Latex (Statens Serum Institut, Denmark). Resistance phenotypes were determined by the double-disk test. Genes were studied by PCR. Maternal colonization was $9.38 \%$. Resistance to erythromycin was $11.6 \%$, and the constitutive phenotype was the predominant one. Serotype Ia was the most frequent, whereas serotypes IV, VI, VII and VIII were not detected. The $l m b, b c a$ and hylB genes were detected in more than $79 \%$ of the strains. In this study, the colonization rate with GBS and the serotype distribution were compared with studies reported in other areas of the country. The high resistance to erythromycin in Misiones justifies performing antibiotic susceptibility testing. The serotype distribution, the genes encoding putative virulence factors, and the patterns of resistance phenotypes of GBS may vary in different areas. They thus need to be evaluated in each place to devise strategies for prevention.
\end{abstract}

Key words: colonization, serotypes, phenotypes, virulence genes.

\section{Introduction}

Although Streptococcus agalactiae or group B streptococcus (GBS) is a normal commensal of the gastrointestinal and genitourinary tracts, according to the Lancefield classification, it is the leading cause of invasive diseases and a well-recognized cause of mortality in human newborns.

Neonates can acquire GBS from their mothers through aspiration of infected amniotic fluid or during the passage through the birth canal.

The colonization of the female genital tract with GBS is significantly associated with this infection and should be carefully monitored.

In Argentina, the prevalence of GBS colonization among pregnant women ranges from 1.4 to $18.15 \%$ (Garcia et al., 2003; Larcher et al., 2005).
With the specific objective to prevent the early-onset of GBS disease in the neonate, the Centers for Disease Control and Prevention (CDC) (Schrag et al., 2002) recommended two strategies to identify mothers colonized with GBS. The strategies consist in identifying important maternal risk factors (previous infant who had invasive GBS disease, GBS bacteriuria during this pregnancy, delivery at $<37$ weeks' gestation, itrapartum temperature $\geq 38^{\circ} \mathrm{C}$, membrane rupture $\geq 18$ hours) or carrying out routine cultures of anogenital swabs obtained from pregnant women at between 35 and 37 weeks of gestation.

If colonization is detected, an antibiotic prophylaxis during delivery is recommended, since it may effectively prevent transmission of GBS to the newborn. In most cases, this prophylaxis results in a significant decrease in invasive neonatal GBS infections (Brimil et al., 2006).

Send correspondence to P. Oviedo. Facultad de Ciencias Exactas, Químicas y Naturales, Universidad Nacional de Misiones, Avenida Mariano Moreno 1375, Posadas, Misiones, Argentina. E-mail: bacterio@fceqyn.unam.edu.ar / drapatriciaoviedo@yahoo.com.ar. 
In our country, the search for GBS in all pregnant women with gestational age between weeks 35 and 37, who either present or not risk factors, has been obligatory by Law N 26369 for the entire nation since April 2008 (http//test.e-legis-ar.msal.gov.ar - 2008).

In GBS, one of the most important virulence factors is the capsular polysaccharide. Thus far, ten capsular capsule polysaccharide serotypes have been found: Ia, Ib, II, III, IV, V, VI, VII, VIII and IX.

The serotype distribution varies with the geographical region and ethnic origin of pregnant women.

Several virulence factors have been identified and associated with the pathogenesis of GBS.

A feature of the GBS strains is that the majority of genes associated with virulence encode proteins necessary for host-bacterial cell interactions and bacterial pathogenicity.

GBS surface proteins include $\alpha-\mathrm{C}$ and $\beta-\mathrm{C}$ proteins, $\mathrm{Rib}$ (resistance to proteases, immunity, group B) protein, HylB protein and Lmb protein.

The $\alpha-C$ protein, encoded by the $b c a$ gene, is associated with epithelial cell adherence, whereas the $\beta-\mathrm{C}$ protein, encoded by the bac gene, is associated with epithelial cell invasion and resistance to phagocyte clearance.

The Rib protein, encoded by the rib gene, shows extensive residue identity with the $\alpha-C$ protein and is expressed by most invasive GBS isolates (Lindahl et al., 2005).

The HylB protein, encoded by the $h y l B$ gene, cleaves hyaluronate chains, facilitating the spread of GBS through host tissues, whereas the Lmb protein, encoded by $\operatorname{lmb}$, mediates the adherence of GBS to human laminin.

GBS surface protein antigens and the genes encoding these proteins are considered important for epidemiological studies of GBS infections, and, some of them, as targets for protective immunity (Areschoug et al., 1999).

The frequency of these proteins and the frequency of the genes encoding them can vary according to the origin of the sample, the characteristics of the population studied, and the geographical location (Manning et al., 2006).

The purpose of this study was to determine the current rate of colonization with GBS in pregnant women, the serotype distribution, the resistance phenotypes and the genes encoding putative virulence factors. In Misiones, Argentina, there are no previous data are available on this topic.

\section{Materials and Methods}

\section{GBS screening}

A total of 3125 pregnant women between 35 and 37 weeks of gestation were enrolled in the study between 2004 and 2010. The vaginal-rectal swabs were collected without speculum. The swabs were placed in Stuart transport media (Ventura Transystem- Medica-Tec Argentina) and trans- ported to the laboratory at room temperature for microbiology analysis. Swabs were incubated in a selective ToddHewitt broth containing colistin $(10 \mu \mathrm{g} / \mathrm{mL})$ and nalidixic acid $(15 \mu \mathrm{g} / \mathrm{mL})$ (Laboratorios Britania-Argentina) for 1824 hours before subculture onto sheep blood agar plates (Agar Columbia- Laboratorios Britania Argentina) for 1824 hours at $37{ }^{\circ} \mathrm{C}$ with $5 \% \mathrm{CO}_{2}$. If GBS was not identified after the incubation for 18-24 hours, the blood agar plates were reincubated and examined at 48 hours to identify suspected organisms.

GBS strains were identified by biochemical standard methods. GBS identification was completed by group B-specific latex agglutination (Phadebact Strep B TestETC International-Bactus AB-Sweden).

\section{Serotype and phenotype determination}

A total of 112 GBS strains were randomly selected and serotyped using a latex agglutination typing kit provided by Statens Serum Institut (Strep-B-Latex. Copenhagen S., Denmark) for the identification of the capsular polysaccharide antigens Ia, Ib, II, III, IV, V, VI, VII, VIII and IX, according to the manufacturer's instructions.

A total of 112 strains erythromycin-resistant phenotypes were determined by the double-disk diffusion method with disks containing erythromycin $(15 \mu \mathrm{g})$ and clindamycin $(2 \mu \mathrm{g})$ onto sheep blood agar plates (Agar Mueller -Hinton - Biokar, Francia) for $18-24$ hours at $37{ }^{\circ} \mathrm{C}$ with $5 \% \mathrm{CO}_{2}$.

Different phenotypes of macrolide-lincosamidestreptogramin B (MLSB) resistance were recognized in accordance with the description of Seppälä et al. (1993) and CLSI recommendations (2010).

Inducible clindamycin resistance by erythromycin was detected by a blunting of the clindamycin zone closest to the erythromycin disk, giving the appearance of a " $D$ " (phenotype iMLS $\mathrm{B}_{\mathrm{B}}$ ).

Resistance to clindamycin (confirmed by the agar dilution method) with no blunting of the clindamycin inhibition zone indicated constitutive resistance $\left(\mathrm{cMLS}_{\mathrm{B}}\right)$.

The M phenotype was characterized by susceptibility to clindamycin with no blunting of the inhibition zone around the clindamycin disk.

\section{Genotype determination}

A total of 88 GBS strains were randomly selected for genotypic determination.

DNA from overnight bacterial colonies was extracted as previously described (Cariaga Martinez and Zapata, 2007; Sambrook and Rusell, 2001).

DNA fragments of the different genes were amplified by polymerase chain reaction (PCR). PCR reactions were cycled 30 times $\left(94{ }^{\circ} \mathrm{C}\right.$ for $30 \mathrm{~s} ; 50{ }^{\circ} \mathrm{C}$ for $60 \mathrm{~s} ; 72^{\circ} \mathrm{C}$ for $60 \mathrm{~s}$ ) with one final cycle at $72{ }^{\circ} \mathrm{C}$ for $2 \mathrm{~min}$ in a thermocycler Multigene TM II (Labnet International Inc., USA). The primers used in this study were: bac (5'-TGTAAAG 
GACGATAGTGTGAAGAC-3') Gene Bank AB221536, bca (5'-CAGGAAGGGGAAACAACAGTAC-3') Gene Bank M97256, rib (5'-CAGGAAGTGCTGTTACGTTA AAC-3') Gene Bank U58333, hylB (5'-TTATCATCCAG CGCCTCCTAG-3') Gene Bank Y15903 and $\operatorname{lmb}$ (5'GACGCAACACACGGCAT-3') Gene Bank AF062533. The primers were synthesized by Operon Molecules for Life (USA).

\section{Statistical analysis}

GBS attack rates were estimated by EPI-INFO 6.5.

Data in relation to the presence or absence of genes encoding putative virulence factors were compared by using the Fisher test. $P$ values below 0.05 were considered statistically significant.

\section{Results}

\section{Colonization rate}

Among the 3125 pregnant women enrolled in the study, 293 (9.38\%) were culture-positive for GBS.

\section{Serotype and phenotype detection}

Serotype Ia was the most common serotype among the isolates, followed by III, V and II.

The overall serotype distribution of GBS was Ia (40\%), III (21\%), V (12\%), II (10\%), Ib (9\%) and IX (4\%).

Four strains were designated as non-typeable.

Serotypes IV, VI, VII and VIII were not found in any of the isolates studied in this work.

Among the 112 isolates, $1.8 \%$ were resistant to clindamycin and $11.6 \%$ were resistant to erythromycin. Among the erythromycin-resistant isolates, nine displayed the constitutive MLSB resistance phenotype, two expressed the inducible MLSB resistance phenotype, and two the $\mathrm{M}$ resistance phenotype.

Six of the thirteen erythromycin-resistant strains belonged to serotype Ia, four to serotype III, two to serotype II and one to serotype $\mathrm{V}$.

\section{Detection of the putative virulence factor genes by PCR}

PCR analysis revealed that 25 of $88(28.4 \%)$ of the strains simultaneously possessed the genes $b c a, b a c, r i b$, lmb and $h y l B$.

Across the colonizing strains, the $\operatorname{lmb}(94.3 \%), b c a$ $(88.6 \%)$ and $h y l B(79.5 \%)$ genes were present in most of the isolates, followed by the rib gene (Table 1).

All except one (an isolate of serotype IX with the rib gene) of the $88 \mathrm{GBS}$ isolates possessed the five genes in different association.

Although all serotypes were distributed among the genes detected in this study, some serotypes were significantly encountered in a particular association: the bac gene with serotype Ia $(\mathrm{p}=0.04), b c a+h y l B$ with serotype $\mathrm{V}$ $(\mathrm{p}=0.02), r i b+h y l B$ and $r i b+b c a+h y l B+l m b$ with serotype III, and $r i b+h y l B$ and $r i b+b c a+h y l B+1 m b$ with serotype IX $(\mathrm{p}=0.04)$.

\section{Discussion}

In this study, the prevalence of GBS colonization among pregnant women in Misiones was of $9.38 \%$.

A well-recognized reservoir site for GBS besides the urogenital tract is the gastrointestinal tract. Specimens obtained with swabs from the lower vagina and the anorrectal area are recommended for GBS screening.

The detection of pregnant women carrying GBS allows intrapartum administration of antibiotic prophylaxis and effectively prevents transmission of bacteria to the newborn.

In this study, all pregnant women colonized with GBS received the intrapartum prophylaxis recommended. All children were born alive and free of infection by GBS.

Our prevalence data are lower than those obtained in previous studies from Argentina like that by García et al. (2003), (18.5\%) but higher than those reported by Larcher et al. (2005).

Table 1 - Frequencies of occurrence of genotypic traits within serotypes of 88 GBS strains.

\begin{tabular}{|c|c|c|c|c|c|c|c|c|c|c|c|}
\hline \multirow[t]{3}{*}{ Serotypes } & \multirow[t]{3}{*}{$\mathrm{N}^{\mathrm{o}}$ of strains } & \multicolumn{10}{|c|}{ Genes } \\
\hline & & \multicolumn{2}{|c|}{$r i b$} & \multicolumn{2}{|c|}{$b a c$} & \multicolumn{2}{|c|}{$b c a$} & \multicolumn{2}{|c|}{$h y l B$} & \multicolumn{2}{|c|}{$\operatorname{lm} b$} \\
\hline & & $\mathrm{N}^{\mathrm{o}}$ & $\%$ & $\mathrm{~N}^{\mathrm{o}}$ & $\%$ & $\mathrm{~N}^{\mathrm{o}}$ & $\%$ & $\mathrm{~N}^{\mathrm{o}}$ & $\%$ & $\mathrm{~N}^{\mathrm{o}}$ & $\%$ \\
\hline Ia & 32 & 23 & 71.9 & 21 & 65.6 & 28 & 87.5 & 24 & 75 & 31 & 96.9 \\
\hline $\mathrm{Ib}$ & 10 & 6 & 60 & 7 & 70 & 7 & 70 & 10 & 100 & 9 & 90 \\
\hline III & 17 & 15 & 88.2 & 6 & 35.3 & 15 & 88.2 & 15 & 88.2 & 16 & 94.1 \\
\hline V & 11 & 9 & 81.8 & 3 & 27.3 & 11 & 100 & 11 & 100 & 10 & 90.9 \\
\hline IX & 4 & 2 & 50 & 3 & 75 & 3 & 75 & 2 & 50 & 3 & 75 \\
\hline NT & 4 & 4 & 100 & 2 & 50 & 4 & 100 & 0 & 0 & 4 & 100 \\
\hline Total & 88 & 67 & 76.1 & 46 & 52.3 & 78 & 88.6 & 70 & 79.5 & 83 & 94.3 \\
\hline
\end{tabular}


Several studies of countries bordering Argentina have reported similar colonization rates: Chile, 19.8\% (Abarzua et al., 2002); Uruguay, 17.3\% (Laufer et al., 2009) and Brazil, 14.6\% (Simões et al., 2007).

In the USA, Regan et al. (1996) detected colonization rates between 15-20\%, whereas in Europe, studies report colonization rates between 6.5 and $36 \%$ (Barcaite et al., 2008).

The prevalence of GBS colonization in the vagina and/or rectum among pregnant women can vary among ethnic groups, geographical locations, and the laboratory procedures carried out on the samples (Ramos et al., 2009; Simões et al., 2007).

In this study, serotype Ia was the most common serotype among the isolates, followed by serotypes III, V and II.

These data are in accordance with studies from Argentina from GBS isolated of invasive infections (Lopardo et al., 2003; Pérez et al., 2004) as well as with other studies from the USA and Europe (Brimil et al., 2006).

Other authors, such as Simoes et al. (2007), reporting GBS colonization rates, have highlighted the prevalence of serotype Ib, followed by serotypes II and Ia. Serotype III comprised only $4.3 \%$ among pregnant women.

In Mexico, Gonzalez et al. (2002) studied 101 GBS strains isolated from the genital tract of pregnant women and informed that serotype I (61.4\%) was the most common serotype.

In the present study, serotypes IV, VI, VII and VIII were not detected. These data can be compared with those obtained by Hickman et al. (1999).

We highlight the presence of serotype IX (in our country not yet reported at the time of this work).

Penicillin is the drug of choice for prophylaxis and treatment of GBS disease, and so far, resistance to this agent has not been reported.

Erythromycin or clindamycin are recommended alternatives for intrapartum antibiotic prophylaxis in penicillin-allergic GBS carriers.

However, recent reports of the increasing incidence of macrolide and clindamycin resistance in different countries have raised concerns about the possibility of inadequate prophylaxis or treatment with these antibiotics as alternative agents in patients allergic to penicillin.

Since 1995, resistance to macrolides and lincosamides has risen in the USA, where resistance values to erythromycin vary from 7 to $21 \%$ and to clindamycin from 3 to $15 \%$. However, in Europe, there are few data concerning this important increase in resistance to macrolides and lincosamide. In a study with strains obtained in Spain (Betriu et al., 2003), a high percentage of resistance to macrolides and lincosamides, similar to that reported in the USA, was found

Two resistance mechanisms have been described: modification by methylation of the antibiotic target, the ri- bosome, and the active efflux of the antibiotic across the membrane.

The most frequently encountered macrolide resistance mechanism in streptococci is target site modification by a methylase encoded by the erm gene, which leads to the inducible or constitutive expression of resistance phenotypes ( iMLS $_{\mathrm{B}}$ and $\mathrm{cMLS}_{\mathrm{B}}$ respectively).

The drug efflux by a membrane-bound protein encoded by a mef gene confers resistance to 14 and 15 membered macrolides ( $\mathrm{M}$ phenotype).

In this study we report the prevalence and mechanisms of macrolide-lincosamide resistance in 112 GBS isolates. Thirteen $(11.6 \%)$ of the isolates were resistant to erythromycin and $2(1.8 \%)$ to clindamycin.

This rate can be compared with data published by our study group (Pegels et al., 2008; Quiroga et al., 2008) from GBS colonizing strains and with data from a Spanish multicenter study (Gonzalez and Andreu, 2004) from GBS colonizing strains and strains isolates from newborns diagnosed with early-onset disease. However, the rate was higher than those reported in Argentina by García et al. (2003), 2.1\% from GBS colonizing strains; Lopardo et al. (2003), 5.2\% from invasive isolates; Mollerach et al. (2007), 2.4\% from invasive and colonizing isolates; Perez et al. (2004), 6\% from isolates from infectious processes and Simoes et al. (2007) in Brazil, and lower than rates reported in Spain (Betriu et al., 2003) and in Taiwan by Hsueh et al. (2001), (46\%).

These differences may be explained by the different policies in the use of antimicrobials in different regions.

All nine erythromycin-resistant isolates of GBS presented the $\mathrm{CMLS}_{\mathrm{B}}$ phenotype, which indicates concomitant constitutive resistance to clindamycin. This result can be compared with data published by Lopardo et al. (2003) and Pérez et al. (2004).

The data of the $\mathrm{iMLS}_{\mathrm{B}}$ phenotype isolates and the risk that such organisms may become resistant to clindamycin suggest that laboratories should consider using the D test on GBS strains who are resistant to erythromycin but susceptible to clindamycin.

The identification of resistant strains in this study suggests that these agents should be used with caution in the prophylaxis or treatment of GBS infection and that periodic surveillance is, therefore, necessary to prompt the appropriate therapeutic choices in patients allergic to $\beta$-lactam agents.

Our data show that six of the thirteen erythromycin-resistant strains belonged to serotype Ia, four to serotype III, two to serotype II and one to serotype V.

Different studies have shown that serotype $\mathrm{V}$ is associated with erythromycin resistance and that this serotype has emerged as a cause of human disease with high propensity to acquire macrolide resistance and spread. In our study, only one serotype $\mathrm{V}$ strain possessed erythromycin resistance. 
In the present study, 88 randomly selected GBS strains were screened for five genes using PCR amplification to assess whether there was any association between the presence or absence of genes encoding putative virulence factors and serotypes.

A total of $28.4 \%$ of the strains simultaneously possessed the genes $b c a, b a c, r i b, l m b$ and $h y l B$.

The statistically significant associations were: $b c a+h y l B$-serotype V $(\mathrm{p}=0.02), \quad r i b+h y l B$ and $r i b+b c a+h y l B+l m b$-serotype III, and rib+hylB and $r i b+b c a+h y l B+l m b$-serotype IX $(\mathrm{p}=0.04)$.

Similarly to that reported by Persson et al. (2008), in this study the genes had a heterogeneous distribution.

It has been reported that the $b a c, b c a$ and rib genes are likely to vary over time and in different populations and geographic locations or in the capsular serotype distribution of the GBS strains. These genes trigger antibody production in animal models (Manning et al., 2006; Persson et al., 2008).

In this study, the genes $b a c, b c a$ and $r i b$ were found at a higher frequency than in other studies from the USA (Manning et al., 2006) and Sweden (Persson et al., 2008): $52.3 \%$ for bac, $88.6 \%$ for $b c a$ and $76.1 \%$ for $r i b$ compared with $20 \%$ and $12 \%$ for $b a c, 29 \%$ and $14 \%$ for $b c a$, and $28 \%$ and $43 \%$ for $r i b$ in the USA and Sweden respectively.

Our study showed the presence of the $\operatorname{lmb}(94.3 \%)$ and $h y l B(79.5 \%)$ genes, thus confirming their presence in most human isolates (Al Safadi et al., 2010).

In previous studies (unpublished data), we did not find the $b c a$ or $r i b$ genes significantly more frequently in invasive vs. colonizing GBS strains and only bac occurred slightly more frequently among invasive $v s$. colonizing isolates $(\mathrm{p}<0.07)$.It is possible that the encoded proteins are differentially expressed and thus, that differences in pathogenicity could be attributable to differences in gene expression.

In agreement with that found in other works (Duarte et al., 2005), bac was never found alone, but only in combination with other genes. Indeed, we found that not all the combinations of genes included $b a c$ as described by Persson et al. (2008).

Overall, we concluded that a more extensive analysis of these genes, including their relationship with the capsular serotype, is needed to contribute with epidemiological data for the development of a GBS vaccine suitable for use in our geographical area.

Our data differ from those obtained by other authors (Manning et al., 2006; Persson et al., 2008) because we did not find an association between a certain serotype and certain gene. None of these associations was statistically significant, except one ( $b a c$ gene-serotype Ia $(\mathrm{p}=0.04)$.

Indeed, we found that not all the combinations of genes included bac as described by Persson et al. (2008).

This study is the first approach with the aim to contribute to a better understanding of the distribution of viru- lence-related genes among GBS isolates from Misiones, Argentina.

The high resistance to erythromycin in Misiones justifies performing antibiotic susceptibility testing.

Up to day the efforts are concentrated on the development of a multivalent conjugate vaccine composed of serotypes Ia, Ib, II, III, V and a protein component (Brimil et al., 2006).

In view of our data, such vaccine will cover the current epidemiological situation in our region.

Our study is the first in Misiones to correlate the distribution of macrolide and clindamycin resistance as well as the frequencies of the genetic determinants encoding for surface proteins potentially associated with virulence among the different serotypes of GBS.

The knowledge of the most prevalent phenotypes in our geographical area is essential to surveillance and appropriate procedures for the control and prevention of the infection.

\section{Acknowledgments}

This study was supported by a grant from Agencia de Investigación Científica and Tecnológica PICTO-UNaM $\mathrm{N}^{\mathrm{o}} 36831$ BID 1728/OC-AR. FONCYT. Ministerio de Ciencia, Tecnología e Innovación Productiva. Universidad Nacional de Misiones.

\section{References}

Abarzua F, Guzmán A, Belmar C, Becker J, García P, Rioseco A (2002) Prevalencia de colonización por Streptococcus agalactiae (grupo B) en el tercer trimestre del embarazo. Evaluación del cultivo selectivo. Experiencia en 2192 pacientes. Rev Chi Obstet Ginecol 67:89-93.

Al Safadi R, Amor S, Hery-Arnaud G, Spellerberg B, Lanotte P, Mereghetti L, Gannier F, Quentin R, Rosenau A (2010) Enhanced expression of $l \mathrm{mb}$ gene encoding laminin-binding protein in Streptococcus agalactiae strains harboring IS1548 in scp B-lmb intergenic region. PLoS One 5:e10794.

Areschoug T, Stålhammar-Carlemalm M, Larsson C, Lindahl G (1999) Group B streptococcal surface proteins as targets for protective antibodies: identification of two novel proteins in strains of serotype V Infect Immun 67:6350-6357.

Barcaite E, Bartusevicius A, Tamaliene R, Kliucinnskas M, Maleckiene L, Nadisauskiene R (2008) Prevalence of maternal group B streptococcal colonization in European countries. Acta Obstet Gynecol Scand 87:260-271.

Betriu C, Culebras E, Gomez M, Rodríguez-Avial I, Sánchez BA, Agreda MC, Picazo JJ (2003) Erythromycin and clindamycin resistance and telithromycin susceptibility in Streptococcus agalactiae. Antimicrob Agents Chemother 47:1112-1114.

Brimil N, Barthell E, Heindrichs U, Kuhn M, Lütticken R, Spellerberg B (2006) Epidemiology of Streptococcus agalactiae colonization in Germany. Int J Med Microbiol 296:39-44.

Cariaga Martinez AE, Zapata PD (2007) Protocolos de Extracción de ADN. In: El laboratorio de Biología Molecular. Edición 
ampliada. Editorial Universitaria de Misiones, Misiones, Argentina, pp. 23-39.

Clinical and Laboratory Standards Institute (2010) Performance standards for antimicrobial susceptibility testing; eighteenth informational supplement. M100-S20, 30.

Duarte RS, Bellei BC, Miranda OP, Brito MA, Teixeira LM (2005) Distribution of antimicrobial resistance and virulence-related genes among Brazilian group B streptococci recovered from bovine and human sources. Antimicrob Agents Chemother 49:97-103.

Garcia SD, Eliseth MC, Lazzo MJ, Copolillo E, Barata AD, de Torres R, Vay CA, Famiglietti AM (2003) Group B Streptococcus carriers among pregnant women. Rev Argent Microbiol 35:183-187.

González A, Ortiz M, Mota R (2002) Serotypes and antimicrobial susceptibility of group B Streptococcus isolated from pregnant women in Mexico. Rev Latinoam Microbiol 44:133136.

González J, Andreu A (2004) Sensibilidad a antimicrobianos del estreptococo del grupo B de transmisión vertical. Estudio multicéntrico. Enferm Infecc Microbiol Clin 22:286-289.

Hickman ME, Rench MA, Ferrieri P, Baker CJ (1999) Changing epidemiology of group B streptococcal colonization. Pediatrics 104:203-209.

Hsueh PR, Teng LJ, Lee LN, Ho SW, Yang PC, Luh KT (2001) High incidence of erythromycin resistance among clinical isolates of Streptococcus agalactiae in Taiwan. Antimicrob Agents Chemother 45:3205-3208.

Larcher JS, Capellino F, De Giusto R, Travella C, Balagione FG, Kreiker G, Cardona HP, Zarate A, Vilaro M, Hernandez D, Ruiz Orrico G (2005) Group B Streptococcus colonization during pregnancy and prevention of early onset of disease. Medicina (Buenos Aires) 65:201-206.

Laufer J, Scasso S, Sosa CG, Rodríguez-Cuns G, Alonso J, Pons JE (2009) Group B Streptococcus colonization among pregnant women in Uruguay. Int J Gynaecol Obstet 104:242243.

Lindahl G, Stålhammar-Carlemalm M, Areschoug T (2005) Surface proteins of Streptococcus agalactiae and related proteins in other bacterial pathogens. Clin Microbiol Rev 18:102-127.

Lopardo HA, Vidal P, Jeric P, Centron D, Paganini H, Facklam RR, Elliott J, Argentinian Streptococcus Study Group (2003) Six-month multicenter study on invasive infections due to group B streptococci in Argentina. J Clin Microbiol 41:4688-4694.

Manning SD, Ki M, Marrs CF, Kugeler KJ, Borchardt SM, Baker CJ, Foxman B (2006) The frequency of genes encoding three putative group B streptococcal virulence factors among invasive and colonizing isolates. BMC Infect Dis 6:116.

Mollerach A, Méndez E, Massa R, Di Conza J (2007) Streptococcus agalactiae aislados en Santa Fe, Argentina: un estudio de la sensibilidad a antibióticos de uso clínico y mecanismos de resistencia a eritromicina y clindamicina. Enf Inf Microb Clin 25:67-68.

Pegels E, Quiroga M, Oviedo P, Pereya E, Galloso P, Vergara M (2008) Caracterización fenotípica de resistencia a macrólidos en Streptococcus agalactiae: primer estudio en Misiones. Rev Cienc Tecnol 10:8-11.

Pérez J, Limansky A, Toresani I, Ebner G, Di Bartolomeo S, de Inocente I, Pretto G, Salazar N, Laferrara M, Bottiglieri M, Ballester D, Morales M, Rivera L, Cacace ML, Castro H, Roldán L, Notario R, Borda N, Cera G, Spoletti MJ, Gregorini E, Sutich EG (2004) Distribución de tipo capsular y sensibilidad a antimicrobiana de Streptococcus agalactiae productores de infecciones en Argentina. Rev Arg Microbiol 36:63-67.

Persson E, Berg S, Bevanger L, Bergh K, Valsö-Lyng R, Trollfors B (2008) Characterization of invasive group B streptococci based on investigation of surface proteins and genes encoding surface proteins. Clin Microbiol Infect 14:66-73.

Quiroga M, Pegels E, Oviedo P, Pereyra E, Vergara M (2008) Antibiotic susceptibility patterns and prevalence of group B Streptococcus isolated from pregnant women in Misiones Argentina. Braz J Microbiol 39:245-250.

Ramos JM, Milla A, López-García P, Gutiérrez F (2009) Estudio de colonización por Streptococcus agalactiae en gestantes extranjeras y españolas, en Elche y Comarca. Carta Científica. Enferm Infecc Microbiol Clin 27:249-251.

Regan J, Klebanoff M, Nugent R, Eschenbach D, Blackwelder W, Lou Yu (1996) Colonization with group B streptococci in pregnancy and adverse outcome. Am J Obstet Gynecol 174:1354-1360

Sambrook J, Rusell DW (2001) Molecular Cloning: a Laboratory Manual. Cold Sprong Harbor, NY.

Schrag S, Gorwitz K, Fultz-Butts K, Schuchat A (2002) Prevention of perinatal group B streptococcal disease. Revised guidelines from CDC. MMWR Recomm Rep 51:1-22.

Seppälä H, Nissinen A, Yu Q, Huovinen P (1993) Three different phenotypes of erythromycin-resistant Streptococcus pyogenes in Finland. J Antimicrob Chemother 32:885-891.

Simões JÁ, Neder Alves V, Fracalanzza SE, Soares de Camargo R, Mathias L, Pires Milanez M (2007) Phenotypical characteristics of group B Streptococcus in parturients. Braz J Infect Dis 11:261-266.

All the content of the journal, except where otherwise noted, is licensed under a Creative Commons License CC BY-NC. 